\title{
The Relationship between Financial Development and Economic Growth for Developing Countries: Panel Causality Analysis
}

Filiz ERATAŞ-SÖNMEZ (https://orcid.org/0000-0003-2052-340X), Department of Economics, Manisa Celal Bayar University, Turkey; e-mail: filiz.eratas@cbu.edu.tr

Yağmur SA ĞLAM (https://orcid.org/0000-0002-8641-7346), Department of Economics, Sinop University, Turkey; e-mail: yagmur.saglam@sinop.edu.tr

\section{Gelişmekte Olan Ülkeler İçin Finansal Gelişim İle Ekonomik Büyüme Arasındaki İlişki: Panel Nedensellik Analizi}

\begin{abstract}
The study aims to examine the relationship between financial development and economic growth in developing countries. In this context, an econometric model has been formed using the financial development index and economic growth variables. Due to the complex nature of the financial system, non-stationary panel data analysis is employed in the empirical model. In the long run, a one-way causality relationship from financial development to economic growth is observed. The findings are in line with the supply-driven approach, which argues for that financial development positively affects economic growth.
\end{abstract}

\section{Keywords $\quad$ : Financial Development, Financial Development Index, Economic Growth, Panel Data Analysis, Panel Causality Analysis.}

JEL Classification Codes : $\quad$ E44, F43, F47, C33.

$$
\text { Öz }
$$

$\mathrm{Bu}$ çalışmanın amacı, gelişmekte olan ülkeler için finansal gelişim ve ekonomik büyüme arasındaki ilişkinin incelenmesidir. Bu bağlamda finansal gelişimi temsil eden finansal gelişmişlik indeksi ile ekonomik büyüme değişkenleri kullanılarak ekonometrik bir model oluşturulmuştur. Finansal sistemin karmaşık yapısı dikkate alınarak, ampirik model kapsamında, dinamik durağan olmayan panel veri analizinden yararlanılmıștır. Analize konu olan ülke grubu için uzun dönemde, finansal gelişmişlikten ekonomik büyümeye doğru tek yönlü bir nedensellik ilişskisinin olduğu sonucuna ulaşılmıştır. Elde edilen bulgular, finansal gelişimin ekonomik büyümeyi olumlu etkilediğini savunan arz çekişli yaklaşımı desteklemektedir.

Anahtar Sözcükler : Finansal Gelişme, Finansal Gelişmişlik İndeksi, Ekonomik Büyüme, Panel Veri Analizi, Panel Nedensellik Analizi. 
Erataş-Sönmez, F. \& Y. Sağlam (2019), "The Relationship between Financial Development and Economic Growth for Developing Countries: Panel Causality Analysis", Sosyoekonomi, Vol. 27(42), 87-106.

\section{Giriş}

Finansal piyasalar ve ekonomik büyüme arasındaki ilişki finansal küreselleşmenin hız kazandığı 1980'li yıllardan itibaren sıkça araştırılmış, finansal piyasaların ekonomik büyüme üzerindeki etkisi ve iki kavram arasındaki nedensellik ilişkisi çeşitli tanımlamalar altında tartışılmıştır. İktisat yazınında sıkça rastlanan "finansal gelişim" kavramı da finansal piyasaların ekonomik büyüme üzerinde neden ve nasıl etkili olduğu hakkında tartışmalara 1şık tutmaktadır. Gelişmiş bir finansal sistem, ekonomik birimlerin sahip olduğu fon fazlasını yatırımlara yönlendirme, yatırım çeşitlendirilmesini sağlama, ortaya çıkabilecek riskleri azaltma, yatırım projeleri için yapılan fizibilite çalışmalarının maliyetlerini düşürme, finansal aracılık ile kaynak dağılımının izlenmesi gibi birbirinden farklı fonksiyonları yerine getirerek ekonomik büyüme sürecini hızlandırmaktadır (Aslan \& Küçükaksoy, 2006: 26).

Finansal piyasalar, özellikle verimlilik artışı ve kaynakların etkin dağılımı yoluyla ekonomik büyümeyi arttırmaktadır. Dış finansman olanağı ile artan girişimcilik sayesinde, daha çok firma faaliyete geçmekte ve bu da firmalar arası rekabeti arttırmaktadır. Ayrıca finansal gelişme ile birlikte firmalar finansman çeşitlendirme yapma imkânı yakalayarak daha iyi bir portföy bileşimi elde edebilmektedir. Dolayısıyla söz konusu firmalar iyileşen mali durumları ve şirket birleşmeleri gibi daha etkin organizasyon yapılarına sahip olmaktadır. Kısacası, finansal gelişme arttıkça firma büyüme performansları da artmaktadır (Beck, 2012: 1).

Finansal sistem yalnızca ekonomik büyüme sürecini hızlandırmakla kalmayıp aynı zamanda bu süreçteki oynaklığın da azalmasını sağlamaktadır. Finansal sistemin varlığı firmaların likidite sıkışıklığını ortadan kaldırıp, uzun dönemli yatırımları kolaylaştırarak ekonomik büyüme rakamlarındaki sapmaları ortadan kaldırmaktadır (Aghion vd., 2009: 495; Aghion vd., 2010: 248). Benzer şekilde, gelişmişmiş bir finansal sistemin varlığı döviz kuru riskini azaltarak firmaların likidite ve yatırım kapasitesi üzerinde olumlu bir etki yaratmaktadır. Örneğin future ve forward anlaşmaları ihracat yapan büyük firmalara katkı sağlayıp belirsizliği ortadan kaldırmaktadır. Geleceğe daha güvenle bakan firmaların performans artışı ekonomik büyümeyi de olumlu yönde etkilemektedir. Ayrıca, gelişmiş bir finansal piyasa para politikası uygulamalarının etkinliğini arttırdığı gibi mali politika uygulamalarının da etki alanını arttırmakta ve daha iyi bir kur rejimi uygulama olanağı tanımaktadır (IMF, 2012: 4-5).

20. yüzyılın başlarından itibaren finansal piyasaların hızlı gelişimine paralel olarak finansal sistemin ekonomik büyüme üzerindeki etkisi sıkça araştırma konusu yapılmıştır ve hala yapılmaktadır. Çünkü bu ikili arasındaki ilişkinin yönü uygulanacak olan ekonomi politikalarının seçimi konusunda oldukça önemlidir. Yapılan çalışmaların genelinde, ülkeler arası ekonomik büyüme farklılıklarının finansal piyasaların yapısal özelliklerinden kaynaklandığı ifade edilmektedir. Ekonomik büyüme ve finans sistemi ilişkinin teorik temelleri Schumpeter (1911) çalışmasına dayandırılmaktadır. Schumpeter'e (1911) göre finansal sistemin, tasarrufların üretken yatırımlara dönüşmesini sağlayan fon aktarım mekanizması sayesinde ekonomik büyümeyi olumlu etkilediğini vurgulamaktadır. 
$\mathrm{Bu}$ çalışma ile birlikte finansal sistem ve ekonomik büyüme arasındaki nedensellik ilişkisinin yönünün belirlenmesi amaçlanmaktadır. Yazında yer alan çalışmalar incelendiğinde, finansal gelişmişlik indeksinin farklı veriler bir araya getirilerek, öznel bir şekilde, yazarlar tarafindan oluşturulduğu ve indeks oluşturma yöntemlerinin farklılaştığı görülmektedir. $\mathrm{Bu}$ çalışmada farklı olarak finansal gelişimi temsil etmesi amacıyla Uluslararası Para Fonu (IMF) geliştirdiği finansal gelişmişlik veri tabanından sağlanan, standartlaştırmış ve bu yönüyle nesnel, finansal gelişmişlik indeksi kullanılmıştır. Ayrıca bu çalışmada, durağan olmayan dinamik panel veri analizi yöntemleri kullanılarak gelişmekte olan ülkeler özel bir sinıflandırma olan EAGLEs (Yükselen ve Büyümenin Öncüsü Ekonomiler: Kartallar) kapsamında ele alınmıştır. Hem ele aldığı ülke grubu hem kullanılan standartlaştırmış finansal gelişmişlik indeksi ile bu çalışmanın alanına katkı sağlaması beklenmektedir.

\section{Yazın Taraması}

Öncül araştırmalarda finansal gelişim ile ekonomik büyüme arasında pozitif bir ilişki olduğuna yönelik önemli bulgular ortaya konmaktadır. İlk ampirik çalışma 1969 yılında Goldsmith tarafından yapılmıştır. Goldsmith (1969), finansal gelişmenin, tasarruf oranlarını artırma ve sermaye birikimini teşvik etme yoluyla ekonomik büyümeyi arttırdığını savunmaktadır. Benzer şekilde, McKinnon (1973) ve Shaw (1973) faiz oranlarının sermaye birikiminde temel belirleyici olduğunu vurgulamakta, finansal serbestleşme ile birlikte finansal gelişme sağlanacağı dolayısıyla da ekonomik büyümeye katkı yapılacağını ifade etmektedirler.

Ekonomi yazınında bu konuda yapılan çalışmaların finansal gelişim ve ekonomik büyüme arasındaki ilişkiyi ele alma şekliyle; nedensellik ilişkisinin analizi ve finansın büyüme kuramlarındaki yerinin incelenmesi temelinde ikiye ayrıldığı görülmektedir. Nedensellik ilişkisinin yönünü araştıran çalışmalar, finansal gelişimin ekonomik büyümeyi arttırdığını savunan arz çekişli yaklaşım ve finansal gelişimin ekonomik büyümeyi takip ettiğini savunan talep itişli yaklaşım olmak üzere iki ana başlık altında toplanmaktadır. Arz öncüllü (supply leading) yaklaşımının temeli Schumpeter (1911) dayanmakta ve bu yaklaşıma göre, finansal sistem ekonomik büyüme için kilit bir role sahiptir. Fon transferi sağlayan finans piyasası, yatırımların gerçekleştirilmesi için ihtiyaç duyulan fonları sağlayarak ekonomik büyümeyi hızlandırmaktadır. İkinci yaklaşım ise Robinson (1954) çalışması ile ilk kez ifade edilen ve ekonomik büyümenin arttıkça finansal gelişimin de artacağını ifade talep takipli (demand following) yaklaşımdır. Ayrıca Demetriades ve Khaled (1996) çalışmasında olduğu gibi finansal gelişim ile büyüme arasında hem arz hem de talep yönlü olmak üzere çift yönlü nedensellik ilişkisinin olduğunu savunan çalışmalara da mevcuttur. Bu çalışmaların yanı sıra Lucas (1988) finansal gelişim ile büyüme arasında nedensellik ilişkisinin olmadığı sonucuna ulaşmıştır.

Değişkenler arasındaki ilişkinin açıklanmasına yönelik teorik yaklaşımlar ise büyüme modelleri kapsamında, ikiye ayrılmaktadır (Durusu-Çiftçi 2015: 68). Bunlardan ilki finansal sistem ile ekonomik büyüme arasındaki ilişkiyi Neo-Klasik büyüme modeli bağlamında ele alan çalışmalardır. Neo-Klasik büyüme teorisine dayanan sınırlı sayıdaki 
Erataş-Sönmez, F. \& Y. Sağlam (2019), “The Relationship between Financial Development and Economic Growth for Developing Countries: Panel Causality Analysis", Sosyoekonomi, Vol. 27(42), 87-106.

çalışmanın temel çıkış noktası, Mankiw vd.'nin (1992) çalışmasında yer alan büyüme modeline hisse senedi piyasası analizinin dâhil edilmesidir. Atje ve Jovanovic (1993) finansal gelişimi, ticareti yapılan hisse senetlerinin toplam değerlerinin ortalaması olarak, ekonomik büyümeyi ise kişi başına düşen milli gelirdeki artış oranı olarak tanımlamışlardır. Yaptıkları ampirik analiz sonucu elde edilen bulgulara göre hisse senedi piyasasında meydana gelen bir finansal gelişim ekonomik büyümeyi anlamlı ve pozitif yönde etkilemektedir. Cooray (2010) çalışmasında, Mankiw vd. (1992) büyüme modelini temel alarak üretim fonksiyonunu hisse senedi piyasalarına uyarlayarak teorik bir yaklaşım sunmuştur. Yapılan ampirik analizin sonuçlarına göre, hisse senedi piyasasındaki gelişmeler uzun dönemde ekonomik büyümeyi arttırmaktadır. Diğer bir teorik yaklaşım ise içsel büyüme modeli çerçevesinde oluşturulan çalışmalardır. Greenwood ve Jovanovic (1990), Bencivenga ve Smith (1991) ile Levine (1991) finansal sistemin, ekonomik büyüme üzerindeki etkisini inceleyen öncü çalışmalar arasında sayılmaktadır.

Greenwood ve Jovanovic (1990) çalışmalarında, finansal aracıların etkin kaynak dağılımını yerine getirdiği ve finansal gelişimin daha yüksek bir ekonomik büyümeye yol açtığını ifade etmektedir. Levine (1991), içsel büyüme teorisi yazınında Romer $(1986,1990)$ ve Lucas'ın (1988) modellerini sentezleyerek, hisse senedi piyasası analizine yer verdiği çalışmasında finansal piyasaların; işlem maliyetlerini azaltarak ticaret hacmi ve verimliliği arttırdığı ayrıca likidite riskini azalttığı için ekonomik büyüme üzerinde olumlu bir etkisinin olduğunu ifade etmektedir. Bencivenga ve Smith (1991), Levine'in (1991) modeline benzer olarak finansal aracıların ekonomik büyüme üzerindeki etkisini inceledikleri çalışmalarında, hisse senedi piyasası yerine bankacılık sektörünü ele almışlar ve tasarrufların finansal piyasalar aracılığı ile üretken yatırımlara dönüştüğünü, bunun da büyüme oranını arttırdığını ifade etmişlerdir.

Saint Paul (1992)'e göre finansal piyasalarda risk; ekonomik birimlerin portföy çeşitlendirmesine olanak tanıması ile dağıtılmaktadır. Dolayısıyla, üretimde daha iyi iş bölümünü beraberinde getiren finansal gelişimin ekonomik büyümeyi artırdığını belirtmiştir. Pagano (1993), AK tipi içsel büyüme modelinden yararlandığı çalışmasında, finansal piyasaların maliyetleri azaltma ve kaynakların etkin dağılımını sağlama fonksiyonları ile ekonomik büyüme üzerindeki etkisini incelemiştir. Finansal gelişmenin genellikle ekonomik büyümeyi pozitif yönde etkilediğini fakat aykırı durumlarında dikkate alınması gerektiğini savunmaktadır. Deidda (2006) diğer içsel büyüme teorisi temelli yaklaşımlardan farklı olarak, finansal piyasaların ekonomik büyümeyi daima teşvik etmeyeceğini belirtmiştir. Ülkelerin ekonomik gelişmede belli bir eşik değere ulaştığında finansal gelişimin içsel olarak meydana geldiğini; finansal gelişim ile bankacılık sektöründe rekabetin beslediği verimlilik artışının ekonomik büyümeyi olumlu yönde etkilediğini belirtmektedir. Wu vd. (2010), diğer araştırmacılardan farklı olarak çalışmalarında ampirik analize yer vermişler ve finansal sistemin kaynakların etkin dağılımı ile büyüme üzerindeki etkisini Pagano (1993) gibi tek sektörlü AK modeli ile incelemişlerdir. Hata düzeltme mekanizmasını kullandıkları uygulamalarından elde edilen sonuç, uzun dönemde değişkenler arasında eş-bütünleşik bir ilişkinin olduğunu ifade etmektedir. Ayrıca hisse senedi piyasası gelişimini ifade eden değişkenler ekonomik büyümeyi pozitif yönde 
etkilerken, bankacılık sektörü gelişimini ifade eden değişkenler ekonomik büyümeyi negatif yönde etkilemektedir.

Alan yazınındaki ampirik çalışmalar incelendiğinde, kullanılan yöntemlerin zaman serisi ve panel veri analizi olmak üzere ikiye ayrıldığı görülmektedir. Bu nedenle çalışmaya konu olan ülke grupları dikkate alınmış ve uygulama yönünden benzerlik gösteren çalışmalara yer verilmiştir. Ancak bu çalışma hem ele alınan ülke grubu hem de ampirik model tahmininde kullanılan güncel ekonometrik yöntemler ve veri seti ile alan yazınında ki diğer çalışmalardan farklılaşmaktadır. 2000'li yıllar sonrasında, panel veri analizinde ortaya çıkan gelişmelerle birlikte, bu yöntem ile yapılan çalışma sayısının arttığ gözlemlenmektedir.

Öncelikle arz öncüllü yaklaşımı destekleyen çalışmalar ele alındığında, Müslümov ve Aras (2002) çalışmalarında 1982-2000 döneminde 22 OECD ülkesi kapsamında ampirik bir model oluşturmuşlar ve elde ettikleri bulgular 1şığında değişkenler arasındaki nedensellik ilişkisinin tek yönlü olup, finansal gelişimden ekonomik büyümeye doğru olduğunu vurgulamışlardır. Christopoulos ve Tsionas (2004) çalışmalarında 1970-2000 döneminde 10 gelişmekte olan ülke için yaptıkları FMOLS analizi sonucunda kısa dönemde değişkenler arasında nedensellik ilişkisi yoktur sonucuna ulaşmışlar fakat uzun dönemde ise finansal gelişimden ekonomik büyümeye doğru bir nedensellik ilişkisinin varlığını vurgulamışlardır. Habibullah ve Eng (2006) panel veri analizinden yararlandıkları çalışmalarında, gelişmekte olan 13 Asya ülkesi için finansal gelişimden ekonomik büyüme doğru arz öncüllü bir nedensellik ilişkisinin olduğunu tespit etmişlerdir. Apergis vd. (2007) çalışmalarında, 19752000 döneminde 15 OECD üyesi ve 50 OECD'ye üye olmayan ülke için finansal gelişim ve büyüme arasındaki ilişkiyi incelemişlerdir. Pedroni eş-bütünleşme testi sonucunda değişkenler arası uzun dönemde eş bütünleşme ilişkisinin olduğu ve panel ARDL analizi ile bu ilişkisinin finansal gelişimden ekonomik büyüme doğru olduğunu belirtmişlerdir. Leitao (2010) çalışmasında, 1980-2006 dönemi AB 27 ülkeleri ve BRIC ülkeleri için yaptığı analiz sonucunda finansal gelişimden ekonomik büyümeye doğru bir nedensellik ilişkisi olduğu sonucuna ulaşmışlardır. Bangake ve Eggoh (2011) 1960-2004 döneminde gelişmiş ve gelişmekte olan toplam 71 ekonomi için yaptıkları çalışmadan elde ettikleri ampirik bulgulara göre, finansal gelişimden ekonomik büyümeye doğru tek yönlü nedensellik ilişkisinin varlığını belirtmişlerdir Ağayev (2012) 1995-2009 dönem için 20 geçiş ekonomisini incelediği Holtz-Eakin vd. panel nedensellik testini uyguladığı çalışmada, değişkenler arasında uzun dönemde eş bütünleşme ilişkisinin olduğunu ve söz konusu ilişkinin arz öncüllü olduğunu vurgulamıştır. Mercan ve Göçer (2013), BRICT ülkelerini analiz ettikleri çalışmalarında finansal gelişimden ekonomik büyümeye doğru yani arz öncüllü bir nedensellik ilişkisinin varlığını savunmuşlardır. Bozoklu ve Yılancı (2013) çalışmalarında, Dumitrescu ve Hurlin panel nedensellik analizinden yararlanmışlardır. 1988-2011 döneminde 13 gelişmekte olan ülke için yapılan nedensellik analizinin sonucunda finansal gelişimden ekonomik büyümeye tek yönlü bir nedensellik ilişkisinin olduğunu tespit etmişlerdir. Aydın vd. (2013) çalışmalarında 1991-2009 dönemi için 23 çevre ekonomisi için finansal gelişim ile ekonomik büyüme arasında uzun dönemde bir nedensellik ilişkisi olmadığı sonucuna ulaşmışlardır. Arıç (2014) 27 Avrupa Birliği ülkesine ait yıllık veriler ile 2004-2012 dönemi için yaptığı analizde, uluslararası finansal krizin 
Erataş-Sönmez, F. \& Y. Sağlam (2019), "The Relationship between Financial Development and Economic Growth for Developing Countries: Panel Causality Analysis", Sosyoekonomi, Vol. 27(42), 87-106.

etkilerinin derinden hissedildiği 2009 yılı dışında değişkenler arasındaki nedensellik ilişkisinin finansal gelişimden ekonomik büyümeye doğru olduğunu savunmuştur. Mhadhbi (2014) çalışmasında 110 ülke için 1973-2012 döneminde yaptığı çalışmada panel veri analizi kapsamında GMM yönteminden yararlanmış, bankacılık sektörü için değişkenler arasında pozitif yönlü ancak özel sektör için negatif bir ilişkinin olduğunu belirtmiştir. Hayaloğlu (2015) 1990-2012 döneminde kırılgan beşli olarak nitelendirilen 5 gelişmekte olan ülkeyi incelediği dinamik panel veri analizinden yararlandığ çalışmasında, değişkenler arasında arz öncüllü bir nedensellik ilişkisinin olduğunu belirtmiştir. Sağlam ve Erataş-Sönmez (2017) Avrupa geçiş ekonomilerini inceledikleri çalışmalarında, temel bileşenler analizi (TBA) yardımıyla finansal gelişmişlik indeksi elde etmişlerdir. Dinamik durağan olmayan panel veri analizinden yararlanılan çalışmada, finansal gelişimden ekonomik büyümeye doğru, arz öncüllü yaklaşımı destekleyen tek yönlü bir nedensellik ilişkisi olduğunu savunmuşlardır. Şahin (2017) çalışmasında, farklı gelir gruplarındaki ülkeler kapsamında söz konusu değişkenler arasındaki nedensellik ilişkisini incelemiş ve 2005-2015 döneminde yüksek gelirli ülkeler ve üst orta gelirli ülkeler için finansal gelişimden ekonomik büyümeye doğru arz öncüllü yaklaşımı destekleyen bir sonuca ulaşmıştır. Erataş-Sönmez ve Sağlam (2018) çalışmalarında, finansal gelişim ile ticari açıklığın ekonomik büyüme üzerindeki etkisini incelemişlerdir. 10 Avrupa Dönüşüm Ekonomisinin analiz edildiği çalışmadan elde edilen ampirik bulgulara göre, arz öncüllü yaklaşımı destekleyen, finansal gelişimden ekonomik büyümeye doğru tek yönlü nedensellik ilişkisi bulunduğunu tespit etmişlerdir.

Talep takipli yaklaşımı destekleyen çalışmalar ele alındığında, Öztürk vd. (2011) 1992-2009 döneminde 9 gelişmekte olan ülkeyi inceledikleri çalışmalarında, panel nedensellik testinden yararlanmışlar ve ekonomik büyümeden finansal gelişime doğru talep yönlü nedensellik ilişkisinin mevcut olduğunu ifade etmişlerdir. Akıncı vd. (2014) çalışmalarında, OECD üye ülkeler için 1980-2011 dönemine ait yıllık veriler ile uyguladıkları Pedroni ved Kao eş-bütünleşme testi sonucunda finansal gelişim ile büyüme arasında uzun dönemde eş bütünleşme ilişkinin mevcut olduğunu vurgulamışlardır. Granger panel nedensellik analizinden elde edilen sonuçlara göre finansal gelişim ile büyüme arasındaki nedensellik ilişkisi ise talep takipli yaklaşımı desteklemektedir.

Finansal gelişim ve ekonomik büyüme arasında çift yönlü nedensellik ilişkisini destekleyen çalışmalar incelendiğinde, Al-Yousif (2002) çalışmasında 1970-1999 döneminde 30 gelişmekte olan ülkesi için finansal gelişim ve büyüme arasındaki ilişkiyi incelemiş, söz konusu iki değişken arasında çift yönlü bir nedensellik ilişkisi olduğu sonucuna ulaşmışlardır. Calderon ve Liu (2003) 1960-1994 döneminde, 109 gelişmiş ve gelişmekte olan ülkeler kapsamında finansal gelişim ve ekonomik büyüme arasındaki nedensellik ilişkisini inceledikleri çalışmada; finansal gelişim ile büyüme arasında çift yönlü bir nedensellik ilişkisi tespit edilmiştir. Acaravcı vd. (2009) çalışmalarında, 1975-2005 döneminde 24 Sahra Altı Afrika ülkeleri için finansal gelişim ve büyüme arasındaki nedensellik ilişkisini panel nedensellik analizi kapsamında incelemişlerdir. Elde ettikleri ampirik bulgulara göre, söz konusu iki değişken arasında uzun dönemde bir ilişki yoktur fakat ekonomik büyüme ve yurtiçi krediler arasında çift yönlü bir nedensellik ilişkisi olduğu sonucuna ulaşmışlardır. Rachdi ve Mbarek (2011) 1990-2006 dönemi için OECD ülkeleri ve 4 MENA ülkesini ele aldıkları çalışmalarında, hata düzeltme modelinden yararlandıkları 
panel veri analizinin sonucuna göre, değişkenler arasında OECD ülkeleri için tek yönlü bir nedensellik ilişkisinin ancak MENA ülkeleri için çift yönlü bir nedensellik ilişkisinin var olduğunu belirtmişlerdir. Hassan vd. (2011) çalışmalarında, 1980-2007 döneminde 168 ülke, 6 farklı coğrafi bölge ve 4 farklı gelir düzeyine sahip ülke grubunu analiz etmişlerdir. Kısa dönemde analize konu olan ülkelerde finansal gelişim ile ekonomik büyüme arasında çift yönlü nedensellik ilişkisinin olduğunu ancak uzun dönemde, yüksek gelir düzeyine sahip ülkelerde GOÜ'lerin aksine değişkenler arasındaki ilişkinin negatife döndüğünü ifade etmişlerdir. Pradhan vd. (2013) çalışmalarında, finansal gelişmişlik endeksini Principal Component Analysis (PCA) ile elde etmiş ve panel VAR analizinden yararlanmışlardır. 1989-2011 döneminde BRIC ülkeleri için yaptıkları analiz sonucunda hem arz yönlü hem de talep yönlü teorik yaklaşımların geçerli olduğunu, değişkenler arasında çift yönlü bir nedensellik ilişkisinin olduğunu vurgulamışlardır. Erataş-Sönmez ve Sağlam (2017) 19932015 döneminde Avro Bölgesi ve Yükselen Avrupa Ülkeleri için panel veri analizinden yararlanmışlardır. Analize konu olan her iki ülke grubu içinde finansal gelişim ile ekonomik büyüme arasında çift yönlü nedensellik ilişkisinin varlığını belirtmişlerdir.

\section{Veri Seti ve Yöntem}

Bu çalışmadaki temel amaç, gelişmekte olan ülkeler kapsamında finansal gelişmişlik ve ekonomik büyüme arasındaki nedensellik ilişkisini incelemektir. Bu doğrultuda analizde gelişmekte olan ülkeleri temsilen EAGLEs ülkelerine (Brezilya, Çin, Meksika, Endonezya, Türkiye, Mısır ve Hindistan) yer verilmiştir. 1980-2016 dönemi, kişi başına düşen reel GSYİH rakamları (G) ve Uluslararası Para Fonu'nun (International Monetary Found-IMF) tarafından 2016 yılında oluşturulan finansal gelişmişlik indeksine (FD) ait yıllık veriler ile bir model oluşturulmuştur.

$$
\begin{aligned}
& G=f(F D) \\
& G_{i t}=\beta_{0}+\beta_{1} F D_{i t}+\varepsilon_{i t} \\
& \text { G: Kişi Başına Düşen GSYİH (2010 Sabit Fiyatları ile, USD) } \\
& \text { FD: Finansal Gelişmişlik İndeksi }
\end{aligned}
$$

İspanya BBVA (Banco Bilbao Vizcaya Argentaria) tarafindan 2010 y1lında gelişmekte olan ülkeler arasında yer alan, yükselen piyasa ekonomisi olarak nitelendirilen Çin, Hindistan, Brezilya, Endonezya, Güney Kore, Rusya, Meksika, Mısır ve Türkiye’yi EAGLEs (Emerging and Growt Leading Economies - Yükselen ve Büyümenin Öncüsü Ekonomiler: Kartallar) olarak sınıflandırmıştır. Söz konusu ülkelerin 2020'li yıllar itibariyle dünya ekonomik büyümesine \%60 ile G7 ülkelerinin \%16'lık ortalama katkısından daha fazlasını olacağı ileri sürülmektedir (BBVA, 2012: 17). Söz konusu artan ekonomik büyümeye sahip ülkelerin milli gelirleri 2014-2024 döneminde G7 milli gelir ortalaması olan 475 milyar ABD dolarından daha fazla olması beklenmektedir. Ayrıca gelişmekte olan ülkelerin 2015-2025 yılları arasında küresel ekonomik büyümenin \%79'unu gerçekleştirmesi bu oranın \%64'ünün de ve EAGLEs ülkelerine ait olacağı tahmin 
edilmektedir (BBVA, 2016: 5-6). Bu çalışmada gelişmekte olan ülkeleri temsil etmesi amacı ile EAGLEs ülkeleri analize dâhil edilmiş, veri kısıtı nedeniyle Rusya ve kişi başına düşen milli gelir oranı ile gelişmiş ülke sınıflandırması içine giren Güney Kore ise dışa düşen veri kaynağı sorunundan kaçınmak amacıyla analiz dışı bırakılmıştır.

Uygulamada kullanılan veri seti IMF veri tabanından elde edilmiştir. Analize konu olan finansal gelişmişlik endeksi açıklanması önemli bir olgudur. Şimdiye kadar yapılan çalışmaların pek çoğu Christopoulos ve Tsionas (2004), Apergis vd. (2007), Bangake ve Eggoh (2009), Hassan vd. (2011), Öztürk vd. (2011), Rachdi ve Mbarek (2011), Ağayev (2012), Aydın vd. (2013), Mercan ve Göçer (2013), Akıncı vd. (2014), Arıç (2014), Mhadhbi (2014), Nasrin ve Mohammad (2014), Hayaloğlu (2015) çalışmalarında olduğu gibi ya finansal gelişmişliği temsil etmesi açısından birbirinden bağımsız farklı değişkenlere yer vermiş ya da Pradhan vd. (2013), Lenka (2015), Sağlam ve Erataş-Sönmez (2017), Erataş-Sönmez ve Sağlam (2017), Erataş-Sönmez ve Sağlam (2018) çalışmalarında olduğu gibi finansal gelişmişliği ifade eden tekil birbirinden farklı değişkenlerin, temel bileşenler analizi (Principal Component Analysis - PCA) yardımıyla doğrusal bir fonksiyonu olarak yeni bir veri setine dönüştürülmesi şeklinde finansal gelişmişlik indeksine yer vermişlerdir.

$\mathrm{Bu}$ çalışmada bağımsız değişken olarak IMF veri tabanından elde edilen ve Svirydzenka tarafından 2016 yılında yayımlanan çalışmaya dayanan "finansal gelişmişlik indeksi” kullanılmıştır. Söz konusu değişken, tekil ve birbirinden bağımsız göstergelerin finansal gelişimi temsil etme ya da açıklamaktaki eksikliğinin üstesinden gelmek için, finansal kurumlar ve finansal piyasalar olmak üzere temelde iki başlık altında toplanan ve her birinin de derinlik, erişim ve verimlilik bakımından nasıl olduklarını özetleyen bir dizi indeks ile finansal gelişmişlik indeksi oluşturulmuştur. Finansal gelişmişlik indeksine ilişkin şema aşağıdaki gibidir:

Şekil: 1

Finansal Gelişmişlik İndeksi Şeması

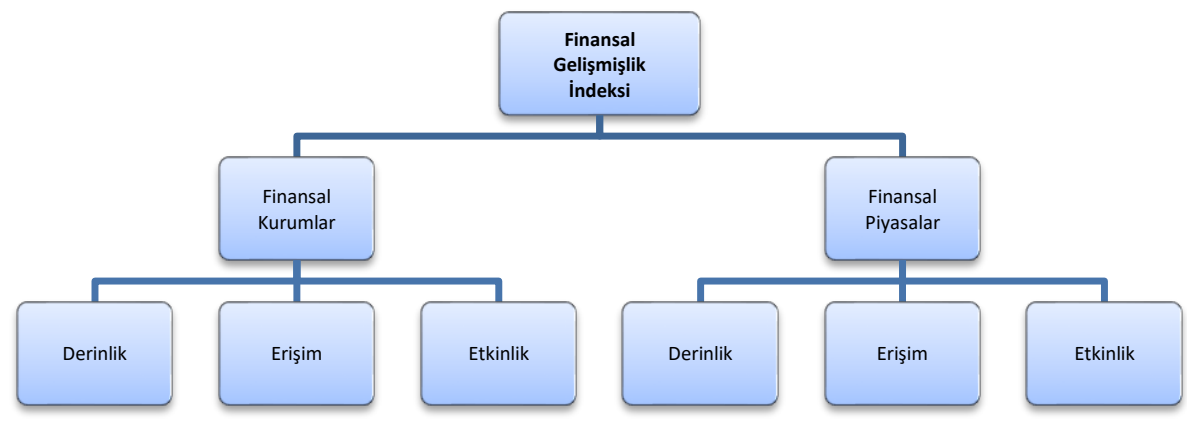

Kaynak: Sahay vd. 2015: 12.

IMF’nin 2016 yılında “finansal gelişmişlik indeksi”, IMF mali erişim anketine ek olarak, Dünya Bankası küresel finansal gelişme veri (GFDD) tabanının daha güncel hali olan 
uluslararası finansal istatistikler (IFS) veri tabanı ile Uluslararası Takas Bankası (BIS) borç menkul kıymetleri veri tabanı ve buna ek olarak Dealogic kurumsal borç veri tabanından ek verilerle desteklenmektedir. Söz konusu veri tabanlarından elde edilen çeşitli bilgiler kullanım kolaylığı açısından birkaç indeksle özetlenmektedir. Finansal sistem özellikleri hakkındaki bilgi mevcudiyeti göz önüne alındığında Dünya Bankası GFDD'de 105 ayrı gösterge ve IFS'de 46 gösterge yer almaktadır Alt endeksler ve nihai endeks bu çeşitli göstergeleri bir araya getirmekte ve finansal sistemlerin belirli özelliklerinin ve genel finansal gelişim seviyesinin kapsamlı bir şekilde değerlendirilmesine olanak sağlamaktadır (Svirydzenka, 2016: 5).

$\mathrm{Bu}$ farklı göstergelerin hepsini ayrı ayrı, özellikle de ampirik çalışmalarda izlemek mümkün değildir. Söz konusu indeks eğer tek başına alınırsa, finansal gelişim seviyesinin kapsamlı bir şekilde anlaşılmasını sağlayacaktır. Bu çalışma ile birlikte finansal gelişmişlik endeksinin tekil kullanım şekli ve değişkenin etkinliği açısından ekonomi yazınına katkı yapması beklenmektedir.

IMF tarafından ayrı bir veri tabanı haline getirilen finansal gelişmişlik indeksi, literatürde çok boyutlu verilerin tek bir özet endeksine indirgenmesinde bulunan standart bir üç aşamalı yaklaşım kullanılarak oluşturulmuş ve izlenilen yöntemin aşamaları aşağıda özetlenmiştir:

- Değişkenlerin normalleştirilmesi,

- Normalleştirilmiş değişkenlerin belirli bir işlevsel boyutu temsil eden alt endekslerde toplanması,

- Alt endekslerin nihai endekste bir araya getirilmesi.

Tablo: 1

Finansal Gelişmişlik İndeksinin Alt İndeksleri ve İndeksleri Oluşturan Temel Göstergeler

\begin{tabular}{|c|c|c|}
\hline Kategori & Değişken & Veri Kaynağı \\
\hline \multicolumn{3}{|c|}{ Finansal Kurumlar } \\
\hline \multirow[t]{4}{*}{ Derinlik } & Özel Sektör Kredileri / GSYİH & Dünya Bankası \\
\hline & Emeklilik Fonu Varlıkları / GSYİH & Dünya Bankası \\
\hline & Yatırım Fonu Varlıkları / GSYİH & Dünya Bankas1 \\
\hline & Sigorta Primleri (Hayat + Diğer Sigortalar) / GSYİH & Dünya Bankası \\
\hline \multirow[t]{2}{*}{ Erişim } & Banka Șubesi Sayısı (100,000 Yetişkin) & Dünya Bankası \\
\hline & ATM Sayısı (100,000 Yetişkin) & Uluslararası Para Fonu \\
\hline \multirow[t]{6}{*}{ Etkinlik } & Net Faiz Marj1 & Dünya Bankası \\
\hline & Borç Verme Yayılımı & Dünya Bankası \\
\hline & Faiz D1ş1 Gelir / Toplam Gelir & Dünya Bankası \\
\hline & Genel Giderler / Toplam Varliklar & Dünya Bankası \\
\hline & Aktif Karlılığ1 & Dünya Bankası \\
\hline & Özkaynak Karlılığ1 & Dünya Bankası \\
\hline \multicolumn{3}{|c|}{ Finansal Piyasalar } \\
\hline \multirow[t]{5}{*}{ Derinlik } & Borsa Kapitilizasyonu / GDP & Dünya Bankası \\
\hline & İşlem Gören Hisse Senedi / GSYİH & Dünya Bankası \\
\hline & Devletin Uluslararası Borçlanma Senedi / GSYİH & Uluslararası Takas Bankası \\
\hline & Finansal Kuruluşların Toplam Borç Senetleri / GSYİH & Dealogic Kurumsal Veri Tabanı \\
\hline & Finansal Olmayan Kuruluşların Toplam Borç Senetleri / GSYİH & Dealogic Kurumsal Veri Tabanı \\
\hline \multirow[t]{2}{*}{ Erişim } & En Büyük 10 Şirket Dışındaki Piyasa Kapitilizasyonu (\%) & Dünya Bankası \\
\hline & Toplam Borç Veren Sayısı (İç+Dış, Finansal+Finansal Olmayan) & Dünya Bankası \\
\hline Etkinlik & Borsa Ciro Oranı (İşlem Gören Hisse Senetleri / Kapitilizasyon) & Dünya Bankası \\
\hline
\end{tabular}


Erataş-Sönmez, F. \& Y. Sağlam (2019), “The Relationship between Financial Development and Economic Growth for Developing Countries: Panel Causality Analysis", Sosyoekonomi, Vol. 27(42), 87-106.

$\mathrm{Bu}$ yöntem için, metodolojik öneriler için iyi bir referans kaynağı olan OECD “Kompozit Göstergeleri Oluşturma El Kitabı”ndan yararlanılmıştır. Söz konusu indeks 1980 yılından itibaren 183 ülke için hesaplanmış ve veri tabanındaki son güncel veri 2016 yılına aittir. İndeks oluşturulurken finansal sistem özelliklerinin farklı yönlerini yakalamak için bir dizi temel gösterge seçilmiştir (Svirydzenka, 2016: 6). Finansal gelişmişlik indeksini oluşturan temel göstergeler aşağıdaki tabloda yer almaktadır:

Tablo 1'de yer alan göstergeler, Şekil 1'de yer alan finansal gelişmişlik indeksine ait piramidin altındaki altı alt indeks halinde toplanır. Üst endeks, ağırlıkların temel bileşenler analizinden elde edildiği ve her bir alttaki serinin katkısını yansıtan temel dizinin ağırlıklı doğrusal bir ortalamasıdır.

FDI değişkenini elde etmek için kullanılan temel bileşenler analizinin amacı, birden çok değişkene sahip olan bir veri setinde boyut sayısını (N) bilgi kaybına yol açmadan azaltmaktır. Joliffe (2002), temel bileşenler analizini veri setinde yer alan değişkenlerin doğrusal bir fonksiyonu olarak tanımlamaktadır. TBA birbirinden bağımsız ve siralı değiş̧kenlerin yeni bir veri setine dönüştürülmesidir (Erataş-Sönmez \& Uysal, 2018: 30). Söz konusu analiz yöntemi, değişkenler arası bağımlılığın ortadan kaldırılması ve boyut indirgemek için sıkça başvurulan bir yöntemdir. Günümüzde indekslerin yer aldığı pek çok çalışma da veri hazırlama tekniği olarak ta kullanılmaktadır.

Temel bileşenler analizi birbiri arasında korelasyon bulunan çok sayıda (p) değişkenin açıkladığı yapıyı, aralarında herhangi bir korelasyon bulunmayan ve orijinal gözlem sayısı p'den az olan k sayıda $(k \leq p)$ orijinal değişkenin doğrusal bileşeni olarak ifade etmektir. Çok değişkenli bir analizde $n$ sayıda birime ait $p$ kadar özellik yer almaktadır. TBA ile oluşturulan yeni veri setinde çoklu doğrusal bağlantı problemine rastlanmamaktadır.

\section{Uygulama Bulguları}

Panel veri, yatay kesit birimlerine ait zaman serisi gözlemlerinin bir araya getirilmesinden oluşmaktadır. Panel veri, yatay kesit ve zaman serisi olmak üzere iki farklı boyuta sahiptir. Bu özelliği sayesinde zaman içerisinde yatay kesit birimlerinde meydana gelen değişmelerin birlikte ele alınmasını olanak tanır ve böylelikle birimler arası (ülke, il, hane halkı, firmalar, borsada işlem gören hisse senetleri, vb.) karşılaştırmalı ekonomik analizlerde sıkça tercih edilmektedir (Sağlam vd. 2017: 154).

Finansal sistemin karmaşık yapısı gereği dinamik ve durağan olmayan panel veri analizinden yararlanılan bu çalışmada, öncelikle değişkenlere ait eğim katsayısının heterojenliği test edilmiştir. Seriye gelecek olası bir ekonomik şokun ülkeleri aynı derecede etkilediğini varsaymak gerçekçi olmayacaktır. Değişkenlere ait eğim katsayılarının heterojenliğinin araştırılması için Pesaran ve Yamagata (2008) Delta testinden yararlanılmıştır. 
Delta testi iki farklı şekilde hesaplanmaktadır $\widetilde{\Delta}$ küçük örneklemlerde delta test istatistiğini temsil etmek için kullanırken, $\tilde{\Delta}_{\text {adj }}$ büyük örneklemlerde delta test istatistiğini temsil etmek için kullanılmaktadır (Göçer, 2013: 229). $\widetilde{\Delta}$ ve $\tilde{\Delta}_{a d j}$ aşağıdaki gibi ifade edilmektedir (Pesaran \& Yamagata: 57):

$$
\begin{aligned}
& \tilde{\Delta}=\sqrt{N} \frac{N^{-1} \check{S}-k}{\sqrt{2 k}} \\
& \tilde{\Delta}_{a d j}=\frac{\sqrt{N} N^{-1} \check{S}-k}{\sqrt{\operatorname{Var}(T, k)}}
\end{aligned}
$$

$k$ açıklayıcı değişken sayısı, $N$ gözlem sayısı, $S$ swamy test istatistiği ve $\operatorname{Var}(T, k)$ ise varyans1 temsil etmektedir. Delta testine ait sifir hipotezi $H_{0}=\beta_{1}=\beta_{2}=\cdots=\beta_{n}=$ $\beta$ (tüm $\beta_{i}^{\prime}$ ler $\left.i c ̧ i n\right)$ değişkenlerin homojen olduğunu varsaymaktadır. Alternatif hipotez ise tam tersini (heterojen olduklarını) $H_{1}=\beta_{1}=\beta_{2}=\cdots \neq \beta_{n}$ (en az bir $\beta_{i}$ için) ifade etmektedir (Pesaran \& Yamagata, 2008: 58).

Tablo: 2

\begin{tabular}{ccc} 
EAGLES Ülkeleri için Delta Test Sonuçları & \\
Test Istatistik Değeri & Olastlk Değeri \\
\hline$\hat{\Delta}$ & 3.602 & 0.000 \\
\hline$\hat{\Delta}_{a d j}$ & 3.753 & 0.000 \\
\hline
\end{tabular}

Tablo 2 incelendiğinde EAGLEs ülkeleri için paneli oluşturan değişkenlere ait hesaplanan olasılık değerleri \%5 güven düzeyinde anlamlı olduğu için heterojendir, yani boş hipotez reddedilmektedir.

Eğim katsayılarının heterojen olduğu ortaya konulan değişkenlerin yatay kesit bağımlılı̆̆ının da incelenmesi gerekmektedir. Seriye gelecek olası herhangi bir içsel ya da dışsal şokun varlığında yatay kesit birimlerinin birbirinden etkilenip etkilenmediği ilerleyen aşamalarda kullanılacak panel birim kök ve panel eş bütünleşme testlerinin türünü belirleyecektir. Yatay kesit bağımlılığının araştırılması için Pesaran $C D_{L M}$ testinden yararlanılmıştır. $H_{0}: \rho_{i j}=\rho_{j i}=\operatorname{cor}\left(u_{i t}, u_{j t}\right)=0, i \neq j$, boş hipotez yatay kesit birimleri arasında herhangi korelasyonun (bağımlılık) bulunmadı̆̆ını ifade etmektedir. Bu test yardımıyla En Küçük Kareler (EKK) yöntemi ile tahminlenen denklemlere ait kalıntılar arasında korelasyon olup olmadığı incelenmektedir.

$C D_{L M}$ test istatistiği şu şekilde hesaplanmaktadır:

$$
C D_{L M}=T \sum_{i=j}^{N-1} \sum_{j=i+1}^{N} \hat{p}_{i j}^{2} \sim \chi_{N(N-1) / 2}^{2}
$$

$p_{i j}$ regresyon denklemlerinde EKK ile tahminlenmesi sonucu elde edilen kalıntılar arasındaki korelasyon katsayısıdır. Kalıntılar arasında bağımlılığın olmadığı sıfır hipotezi altında $L M$ istatistiği, yatay kesit birim sayısı sabitken ve zaman sonsuza giderken $\chi^{2}$ dağılımı göstermektedir (Pesaran, 2004). Elde edilen bulgular aşağıdaki gibidir: 
Tablo: 3

Model İçin $\mathrm{CD}_{\mathrm{LM}}$ Testi Sonuçları

\begin{tabular}{lcc} 
Test & Test İstatistik Değeri & Olasılık Değeri \\
\hline LM (Breusch ve Pagan, 1980) & 108.093 & 0.000 \\
CD (Pesaran, 2004) & 13.439 & 0.000 \\
$C D_{L M}$ (Pesaran, 2004) & 5.676 & 0.000 \\
\hline Düzeltilmiș CD (Pesaran vd., 2008) & 7.980 & 0.000 \\
\hline
\end{tabular}

Tablo: 4

G Değişkeni İçin $\mathrm{CD}_{\mathrm{LM}}$ Testi Sonuçları

\begin{tabular}{lcc} 
Test & Test İstatistik Değeri & Olasslık Değeri \\
\hline LM (Breusch ve Pagan, 1980) & 32.751 & 0.049 \\
CD (Pesaran, 2004) & 1.813 & 0.035 \\
$C D_{L M}$ (Pesaran, 2004) & -3.615 & 0.000 \\
\hline Düzeltilmiş CD (Pesaran vd., 2008) & 83.337 & 0.000 \\
\hline
\end{tabular}

Tablo: 5

FD Değişkeni İçin $C_{L M}$ Testi Sonuçları

\begin{tabular}{lcc} 
Test & Test İstatistik Değeri & Olasilık Değeri \\
\hline LM (Breusch ve Pagan, 1980) & 38.491 & 0.010 \\
CD (Pesaran, 2004) & 2.768 & 0.003 \\
$C D_{L M}$ (Pesaran, 2004) & -3.857 & 0.000 \\
\hline Düzeltilmiș CD (Pesaran vd., 2008) & 19.740 & 0.000 \\
\hline
\end{tabular}

Tablo 3, 4 ve 5 incelendiğinde hem model hem de değişkenlerin her biri için yatay kesit birimleri arasında bağımlılığın olduğu görülmektedir. Tabloda yer alan olasılık değerleri \% 5 'te anlamlıdır ve G ile FD değişkenleri için kesit bağımsızlığını ifade eden sıfır hipotezi kabul edilmemektedir.

Yatay kesit bağımlılığı ispatlanan değişkenler arası eş bütünleşme ilişkisinin analizinden önce, değişkenlerin durağanlığı araştırılmalıdır. Bu çalışmada, değişkenlerin durağanlığının araştırılması için yatay kesit bağımlılı̆̆ını dikkate alan ikinci nesil panel birim kök testleri uygulanmıştır. Paneli oluşturan seriye gelen herhangi bir şok sonrasında serisinin ortalaması ve / veya varyansı eski haline geri dönmemektedir (Sağlam \& Egeli, 2013: 30).

Panel birim kök sınaması için öncelikle Pesaran (2007) CADF (Cross-sectionally Augmented Dickey Fuller - Yatay Kesite Uyarlanmış Dicky Fuller) testinden yararlanılmış, bu test ile hesaplanan gecikme değerleri kullanılarak Hadri Kurozumi (2012) testi sonuçlarına da yer verilmiştir. Pesaran (2007), hata terimlerinin faktör yapılarını tahminleyen bir test yerine yatay kesit bağımlılığını dikkate alan ve kesit açısından uyarlanmış bir test geliştirmiştir. $C A D F$ testi aşağıdaki regresyonun tahminine dayalıdır (Pesaran, 2007: 268):

$$
\Delta Y_{i t}=\alpha_{i}+b_{i} y_{i, t-1}+\sum_{j=1}^{\rho_{i}} c_{i j} \Delta Y_{i, t-j}+d_{i} t+h_{i} \bar{y}_{i, t-j}+\sum_{j=0}^{\rho_{i}} \eta_{\ddot{u}} \Delta \bar{y}_{i, t-j}+\varepsilon_{i, t}
$$

$H_{0}: b_{i}=0$, seri durağandır boş hipotezi altında değişkenler için elde edilen $\mathrm{t}$ istatistik değerleri, Pesaran (2007) kritik değerleri ile karşılatırılır. CADF testi yatay kesit birimi sayısının zaman boyutundan büyük veya küçük olması durumunda da etkin sonuçlar vermektedir. CIPS istatistiği eğim katsayısının heterojen olduğu değişkenler için kullanılan 
ve her bir yatay kesit birimi için hesaplanan $t$ istatistiklerinin ortalamasını ifade etmektedir (Sağlam vd., 2017: 156-157).

Tablo: 6

CADF Birim Kök Testi Sonucları

\begin{tabular}{|c|c|c|}
\hline Değişkenler & \multicolumn{2}{|c|}{ G } \\
\hline Ülkeler & $\begin{array}{c}\text { Düzey } \\
\text { Sabit ve Trend }\end{array}$ & $\begin{array}{c}\text { Birinci Farkı } \\
\text { Sabit ve Trend }\end{array}$ \\
\hline Brezilya & -3.1052 & -3.5125 \\
\hline Çin & -2.4381 & -3.6633 \\
\hline Meksika & -3.4179 & $-2.8008^{*}$ \\
\hline Endonezya & -1.9411 & -3.2765 \\
\hline Türkiye & -2.3332 & -3.7604 \\
\hline Misır & -3.3119 & $-2.2199^{*}$ \\
\hline Hindistan & -1.4314 & -4.0500 \\
\hline \multirow[t]{2}{*}{ CIPS } & -2.5684 & -3.3262 \\
\hline & \multicolumn{2}{|c|}{ FD } \\
\hline Ülkeler & $\begin{array}{c}\text { Düzey } \\
\text { Sabit ve Trend }\end{array}$ & $\begin{array}{c}\text { Birinci Farkı } \\
\text { Sabit ve Trend }\end{array}$ \\
\hline Brezilya & -3.0019 & -4.5379 \\
\hline Çin & -1.2520 & -3.4195 \\
\hline Meksika & -3.6686 & -4.0446 \\
\hline Endonezya & -3.5264 & -4.4889 \\
\hline Türkiye & -3.1638 & -3.3577 \\
\hline Misir & -2.0511 & -4.2305 \\
\hline Hindistan & -2.7015 & $-2.692 *$ \\
\hline CIPS & -2.7665 & -3.8244 \\
\hline
\end{tabular}

Max. gecikme uzunluğu 4 alınmış ve optimal gecikme uzunlukları Akaike-AIC ve Schwarz-SIC bilgi kriterlerine göre belirlenmiştir. CADF test istatistiğine ait kritik değerler sabit ve trend içeren modelde -4.67 (\%1), -3.87 (\%5) ve -3.49 (\%10) (Pesaran, 2007: Tablo 1(c), 276)'da yer almaktadır. Panel istatistiği (CIPS), CADF istatistiklerinin ortalamasıdır. Paneli oluşturan değişkenler heterojen oldukları için her bir yatay kesit birimi için hesaplanan CADF test istatistik değerleri dikkate alınmaktadır. Tablo 6 incelendiğinde hesaplanan t-istatistik değerleri düzeyde genel olarak Pesaran (2007) kritik değerlerinden büyük olduğundan (* simgesi ile ifade edilenler hariç) $H_{0}$ hipotezi her iki değişken için ayrı ayrı reddedilmektedir. Değişkenler düzeyde birim kök içermekte ve birinci farkları alındıktan sonra durağan hale gelmektedirler.

Hadri Kurozumi (HK) birim kök testi, KPSS testinin panel veri setleri için uyarlanmış şeklidir ve Pesaran (2007) CADF testinden yararlanılarak geliştirilmiştir. Bu testte CADF testinde olduğu gibi yatay kesit bağımlılığını dikkate almaktadır. CADF testinde yer alan sıfır hipotezi ve alternatif hipotez yer değiştirmektedir. Böylece CADF testinin sahte birim kökün varlığına karşı güçsüzlüğü ortadan kaldırılmış olmaktadır (Hadri ve Kurozumi 2012: $31)$ :

$$
\begin{aligned}
& y_{i t}=z^{\prime}{ }_{t} \delta_{i}+f_{t} \gamma_{i}+\varepsilon_{i t} \\
& \varepsilon_{i t}=\emptyset_{i p} \varepsilon_{i t-1}+\cdots+\emptyset_{i 1} \varepsilon_{i t-p}+v_{i t}
\end{aligned}
$$

$i=1, \ldots, N$ ve $t=1, \ldots, T$ iken $z_{t}$ deterministik yani hesaplanabilir ve bağımlı değişkendeki değişimi açıklayabilmektedir. Teste ait sıfır hipotezi CADF testinden farklı olarak serinin durağan olduğunu ifade etmektedir. HK testinde iki farklı test istatistiği 
kullanılmaktadır. $Z_{A}^{S P C}$ ve $Z_{A}^{L A} \mathrm{~N}$ ve T sonsuza yaklaşırken normal dağılıma sahiptir. Testten elde edilen bulgular aşağıdaki tablolarda verilmiştir:

Tablo: 7

HK Birim Kök Testi Sonuçları

\begin{tabular}{cccc} 
Test & & Test İstatistik Değeri & Olasılık Değeri \\
\hline GDP & & -0.8872 & 0.8125 \\
& $Z_{A}^{S P C}$ & -2.0816 & 0.9813 \\
\hline & $Z_{A}^{L A}$ & -0.2825 & 0.6112 \\
\hline \multirow{2}{*}{ DDI } & $Z_{A}^{S P C}$ & 3.7063 & 0.0001 \\
\hline & $Z_{A}^{L A}$ & & \\
\hline
\end{tabular}

Testte yer alan optimal gecikme uzunluğu AIC ve SIC bilgi kriterlerine göre belirlenmiştir. $Z_{A}^{S P C}$ uzun dönem varyansın Sul vd. (2005) yöntemiyle hesaplanan panel genişletilmiş KPSS test istatistiğini ifade etmektedir. $Z_{A}^{L A}$ uzun dönem varyansın Choi (1993), Toda ve Yamamato (1995) yöntemiyle hesaplandığı panel genişletilmiş KPSS test istatistiğini ifade etmektedir. Tablo 7'de görüldüğü üzere değişkenlerin olasılık değerleri 0.05 'ten büyük ve anlamsızdır. Yani değişkenler düzeyde birim kök içermektedirler ve edilen sonuçlar CADF testi sonuçlarını desteklemektedir.

Panel veri analizinde kullanılan panel eş bütünleşme testlerinin yapısı değişkenlerin yatay kesit baımlılı̆̆ı / bağımsızlı̆̆ı ve heterojenite / homojenite özelliklerine göre değişmektedir. Çalışmada kullanılan değişkenler heterojen ve yatay kesit bağımlılığına sahip olduğu için Durbin Hausmann eş bütünleşme testi kullanılmıştır. Westerlund (2008) tarafından geliştirilen DH yatay kesit bağımlılığını dikkate almakta birlikte, gözlem sayısının zaman boyutundan küçük olduğu durumlarda da etkin sonuçlar vermektedir (Westerlund, 2008: 195).

Durbin Hausmann testine ait $D H_{g}$ paneli oluşturan değişkenlerin eğim katsayıalrı heterojen olması durumunda dikkate alınırken ve $D H_{p}$ paneli oluşturan değişkenlerin eğim katsayıları homojen olduğunda dikkate alınmaktadır (Westerlun, 2008: 198-199). Boş hipotez bütün yatay kesit birimleri için eş bütünleşme ilişkisinin olmadığını ifade etmektedir.

Tablo: 8

EAGLEs Ülkeleri için DH Testi Sonuçları

\begin{tabular}{ccc} 
Test & Test İstatistiği & Olasslık Değeri \\
\hline$D H g$ & 2.025 & $0.021^{*}$ \\
\hline$D H p$ & -1.612 & 0.947 \\
\hline
\end{tabular}

*: \%5'te anlamlıllğı ifade etmektedir.

Tablo 8 incelendiğinde verilerin heterojen olduğu durumda dikkate alınan $D H_{g}$ test istatistiğinin olasılık değeri istatistiki olarak anlamlı olduğu anlaşılmaktadır. Bu nedenle değişkenler arasında eş bütünleşme olmadığını varsayan boş hipotez reddedilmektedir, değişkenler arası eş bütünleşme ilişkisi vardır bu da G ve FD değişkenlerinin uzun dönemde birlikte hareket ettiği anlamına gelmektedir. Ayrıca paneli oluşturan değişkenlerin heterojen olup olmamalarının yarattığı fark tabloda yer alan sonuçlardan açıkça görülmektedir. 
Panel nedensellik yazınına yön veren dört temel test mevcuttur. Bunlardan biri de Granger nedensellik testi ile benzerlik gösteren Dumetriscu Hurlin (2012) DH panel nedensellik testidir. Ancak panel Granger nedensellik testinden farklı olarak eş bütünleşme ilişkisinin varlığı ya da yokluğu durumunda da uygulanabilmektedir. Bu testin bir başka avantajı ise yatay kesit bağımlılığı / bağımsızlığı ayrıca homojenite / heterojenite varlığında da uygulanabilir olmasıdır. Üç farklı test istatistiğinin (Whnc, Zhnc, Ztild) kullanıldığı bu testte boş hipotez $H_{0}: \beta_{i}=\forall_{i}=1,2 \ldots, N$ değişkenler arasında nedensellik ilişkisinin olmadığını ifade etmektedir (Dumetriscu \& Hurlin, 2012: 4-5).

Whnc homojen verilerin varlığında kullanılanır ve ki kare dağılımı gösterir. Zhnc $\mathrm{N}$ ve T'nin büyük olduğu durumlarda kullanılırken Ztild ise $\mathrm{T}>5+2 \mathrm{~K}$ ya da $\mathrm{T} \geq 6+2 \mathrm{~K}$ durumlarında kullanılmaktadır ve her iki test istatistiği de normal dağılım göstermektedir (Dumetriscu \& Hurlin 2012: 1543-1554).

\begin{tabular}{rcc} 
& \multicolumn{1}{c}{ Tablo: 9 } \\
Boș Hipotez & DH Panel Nedensellik Testi Sonuçları & \\
Test İstatistik Değeri & Olasılık Değeri \\
\hline G, FD'nin Granger nedeni değildir & & $9.58 \mathrm{E}-10$ \\
Whnc & 6.300332 & 0.039400 \\
Zhnc & 2.151764 & 0.138123 \\
\hline Ztild & 1.456482 & $2.95 \mathrm{E}-12$ \\
\hline FD, G'nin Granger nedeni değildir & & 0.005057 \\
\hline Whnc & 7.159759 & 0.043725 \\
\hline
\end{tabular}

Tablo 9'da yer alan sonuçlar incelendiğinde EAGLEs ülkeleri için değişkenler arasındaki nedensellik ilişkisinin $\% 5$ anlamlılık düzeyinde tek yönlü olduğu anlaşılmaktadır. EAGLES ülkeleri için finansal gelişimden ekonomik büyümeye doğru tek yönlü bir nedensellik ilişkisi vardır. Dumetriscu Hurlin (2012) panel nedensellik testinde hesaplanan Ztild değerleri dikkate alınmaktadır, bunun sebebi ise analize konu olan zaman aralığının $\mathrm{T}>5+2 \mathrm{~K}$ ve / veya $\mathrm{T} \geq 6+2 \mathrm{~K}$ yani $37>5+2(1)$ ve / veya $37 \geq 6+2(1)$ olmasidır.

\section{Sonuç}

Finansal gelişim ve ekonomik büyüme arasındaki nedensellik ilişkisinin yönünün belirlenmesi, politika seçimi konusunda önemli bir rol oynamaktadır. Ekonomi yazınında nedenselliğin yönünün açıklamaya yönelik pek çok çalışma bulunmaktadır. Bu çalışmanın ekonomi yazınında yer alan diğer çalışmalardan farkı, ele aldığı ülke grubu ile uyguladığ analiz yöntemi ve çalışmada kullanılan veri setinin güncelliğidir. Çalışmada "EAGLEs" olarak sınıflandırılan finansal küreselleşme ile birlikte neo-liberal ekonomi politikalarını benimsemiş yükselen piyasa ekonomileri olarak nitelendirilen gelişmekte olan ülkeler analize konu edilmiştir. Söz konusu ekonomiler dünya ekonomisinin geleceği adına ekonomik büyüme açısından önemli bir rol üstlenmektedir.

Finansal piyasaların karmaşık yapısından ötürü dengeden uzak olması nedeniyle çalışmada durağan olmayan dinamik panel veri analizine yer verilmiştir. Ayrıca oluşturulan modelde $\mathrm{T}>\mathrm{N}$ olan gözlem sayısı sebebiyle de baskın zaman etkisini dikkate alan bu 
Erataş-Sönmez, F. \& Y. Sağlam (2019), “The Relationship between Financial Development and Economic Growth for Developing Countries: Panel Causality Analysis", Sosyoekonomi, Vol. 27(42), 87-106.

yönteme başvurulması gerekmektedir. Elde edilen ampirik bulgulara göre, modelde yer alan değişkenlerin eğim katsayıları heterojendir, bu seriye gelecek herhangi bir şokun yatay kesit birimlerini aynı derecede etkilemediği anlamına gelmektedir. Ayrıca paneli oluşturan değişkenler yatay kesit bağımlılığı özelliği göstermektedir. Bunun anlamı, seriye gelen bir şok karşısında yatay kesit birimlerinin birbirinden etkilendiğidir. Elde edilen heterojenlik ve yatay kesit bağımlılığı bulguları 1şığında uygulanan panel birim kök ve panel eş bütünleşme testlerinin yapısal özelliklerine karar verilmiştir. Bu çalışmada, değişkenlerin yatay kesit bağımlılı̆̆ özelliğine sahip olmasından dolayı ikinci nesil panel birim kök testlerinden yararlanılmış ve elde edilen sonuçların güvenilirliğinin test edilmesi amacıyla ikinci bir panel birim kök testi olan HK testine de yer verilmiştir. Uzun dönemde değişkenler arası eş bütünleşik ilişkinin varlığını incelenebilmesi için yatay kesit bağımlılığını dikkate alan ikinci nesil eş bütünleşme testlerinden biri olan Durbin-H panel eş bütünleşme testi kullanılmıştır. Elde edilen sonuçlara göre, değişkenler arasında eş bütünleşik ilişki vardır ve uzun dönemde ampirik modelde yer alan G ile FDI değişkenleri birlikte hareket etmektedir.

Finansal gelişim ve ekonomik büyüme arasındaki nedensellik ilişkisinin yönü DH panel nedensellik testi ile analiz edilmiştir. Uygulama bulguları değerlendirildiğinde, EAGLEs olarak sınıflandırılan gelişmekte olan ülkeler için finansal gelişimden büyümeye doğru tek yönlü nedensellik ilişkisinin bulunduğu sonucuna ulaşılmaktadır. Bu bağlamda yapılan çalışmanın ortaya koyduğu sonuç, finansal gelişimin büyümeyi pozitif yönde etkilediğini savunan arz çekişli yaklaşımı desteklenmektedir. Bu çalışmada ortaya konan değişkenler arası nedensellik ilişkisinin arz yönlü yaklaşımı desteklemesi sonucu ile Christopoulos ve Tsionas (2004), Apergis vd. (2007), Bangake ve Eggoh (2009), Ağayev (2012), Mercan ve Göçer (2013), Arıç (2014), Hayaloğlu (2015), Sağlam ve Erataş-Sönmez (2017) ve Erataş-Sönmez ve Sağlam (2018) çalışmalarından elde edilen sonuçlar benzerlik göstermektedir.

Çalışmadan elde edilen sonuçlar doğrultusunda, finansal gelişim ve büyüme arasındaki arz öncüllü nedensellik ilişkisine dayanarak finansal derinleşmesinin arttıkça ülkelerin ekonomik büyümelerinin artacağını söylemek mümkündür. EAGLEs kapsamında ele alınan ülkelerin finansal küreselleşme doğrultusunda finansal sistemlerinin dışa açılma süreçleri incelendiğinde bu sürecin ne kadar etkin bir şekilde gerçekleştirildiği tartışmalıdır. Finansal sistemin derinliği henüz tam sağlanmadan uluslararası piyasalara entegre olmaya çalışan bu ülkelerin finansal yapılarının kırılganlıklarının yüksek olduğu bir gerçektir. Tam da bu nedenle, çalışmanın arz öncüllü yaklaşımı destekleyen ve finansal gelişimden ekonomik büyümeye doğru olduğu vurgulanan nedensellik ilişkisi dikkate alınmalıdır. Söz konusu ülkelerde finansal küreselleşmenin etkisiyle reel getiriler önemini yitirerek spekülatif kazançların üretken yatırımlara baskın çıktığı görülmektedir. İstikrarsız bir finansal sistem artan kırılganlık nedeniyle krizlere yatkın hale gelmektedir ve söz konusu krizler daha sonra uluslararası bir hal kazanarak, ulusal ekonomi politikalarının da denetimini güçleşmektedir. Finansal gelişimden büyümeye doğru olan nedensellik ilişkisi, gelişmekte olan ülkeler için finansal piyasalardaki derinliğin ekonomik büyüme performansının sürdürülebilirliğini sağladığını açıkça göstermektedir. $\mathrm{Bu}$ bulgu ile ekonomik büyümenin sürdürülebilmesi için oluşturacak yeni politika önermelerinde finansal sistemin etkinliği ve derinleşmesi kavramlarına öncelik verilmesi gerektiği görülmektedir. 
Ancak unutulmamalıdır ki ekonometrik uygulamalar tek başına genel geçer bir çözüm önerisi sunmamaktadır. Güncel ekonometrik yöntemleri araç olarak kullanan iktisadi analizlerin teorik temellere dayandırılması bir zorunluluktur.

Sürdürülebilir ekonomik büyüme gelişmekte olan ülkelerin karşılaştıkları temel sorunlar arasında yer almaktadır. Finansal gelişmişliğin artmasını amaçlayan ekonomi politikaları temelde ekonomik büyümeyi arttırmayı hedeflemektedir. Ülkelerin içinde bulunduğu farklı yapısal koşullar dikkate alınmadan uygulamaya konacak bir ekonomi politikası başarılı olamayacaktır. Farklı sınıflandırmalar altında farklı pek çok analize konu olan gelişmekte olan ülkeler için, ülkelere özgü ekonomin yapısal sorunlara da yer verilen, finansal piyasalar ile reel piyasanın özellikle ekonomik büyüme adına birbirinin rakibi değil tersine birbirini tamamlayıcı iki unsur olduğu gözetilerek, yeni politika önerilerinde bulunulmalı ve ülkelere özgü yapısal sorunların kaynaklarına yönelik çözüm önerileri sunulmalidir.

\section{Kaynaklar}

Acaravc1, A. \& İ. Öztürk \& S.K. Acaravcı (2007), "Financial Development and Economic Growth: Literature Survey and Empirical Evidence from Sub-Saharan African Countries", South African Journal of Economic and Management Sciences, 12(1), 11-27.

Ağayev, S. (2012), “Geçiş Ekonomilerinde Finansal Gelişme ve Ekonomik Büyüme İlişkisi”, Marmara Üniversitesi İIBF Dergisi, 32(1), 155-164.

Akıncı G.Y. \& M. Akıncı \& Ö. Yılmaz (2014), "Financial Development Economic Growth Nexus: A Panel Data Analysis upon OECD Countries", Hitotsubashi Journal of Economics, 55(1), 33-50.

Al Yousif, Y.K. (2002), "Financial Development and Economic Growth: Another Look at the Evidence from Developing Countries", Review of Financial Economics, 11, 131-150.

Apergis N. \& L. Flippidis \& C. Economidou (2007), "Financial Deepening and Economic Growth Linkages: A Panel Data Analysis", Review of World Economics, 143(1), 179-198.

Arıç, K.H. (2014), "The Effects of Financial Development on Economic Growth in the European Union: A Panel Data Analysis", International Journal of Economic Practices and Theories, 4(4), 466-471.

Aslan, Ö. \& İ. Küçükaksoy (2006), "Finansal Gelişme ve Ekonomik Büyüme İlişkisi: Türkiye Ekonomisi Üzerine Ekonometrik Bir Uygulama", İstanbul Üniversitesi İktisat Fakültesi Ekonometri ve İstatistik Dergisi, 4, 12-28.

Atje, R. \& B. Jovanovic (1993), "Stock Markets and Development”, European Economic Review, $37,632-640$.

Bangake, C. \& J.C. Eggoh (2011), "Further Evidence on Finance-Growth Casuality: A Panel Data Analysis", Economic Systems, 35(2), 176-188.

Banco Bilbao Vizcaya Argentaria - BBVA (2012), Annual Report, <https://www.bbvaresearch.com/KETD/fbin/mult/120215_BBVAEAGLES_Annual_Rep ort_tcm348-288784.pdf>, 09.03.2019.

Beck, T. (2012), Finance and Growth - Lessons from the Literature and the Recent Crisis, <http://www.lse.ac.uk/researchAndExpertise/units/growthCommission/documents/pdf/co ntributions/lseGC_beck_Finance.pdf $>, 1-6,15.08 .2019$. 
Erataş-Sönmez, F. \& Y. Sağlam (2019), “The Relationship between Financial Development and Economic Growth for Developing Countries: Panel Causality Analysis", Sosyoekonomi, Vol. 27(42), 87-106.

Bencivenga, V.R. \& B.D. Smith (1991), "Financial Intermediation and Endogenous Growth", The Review of Economic Studies, 58(2), 195-209.

Bozoklu, Ş. \& V. Yılancı (2013), "Finansal Gelişme ve İktisadi Büyüme Arasındaki Nedensellik İlişkisi: Gelişmekte Olan Ekonomiler İçin Analiz", Dokuz Eylül Üniversitesi İktisadi ve Ídari Bilimler Fakültesi Dergisi, 28(2), 161-187.

Breusch, T.S. \& A.R. Pagan (1980), "The Lagrange Multiplier Test and Its Applications to Model Specification in Econometrics", The Review of Economic Studies, 47(1), 239-253.

Christopoulos, D.K. \& E.G. Tsionas (2004), "Financial Development and Economic Growth: Evidence from Panel Unit Root and Cointegration Test", Journal of Development Economics, 73(1), 55-74.

Choi, I. (1993), Improving Empirical Size of the KPSS Test of Stationary, <http://hompi.sogang.ac.kr/inchoi/workingpaper/in_choi-jetem-revision_2.pdf>, 05.03.2019.

Cooray, A. (1993), “Do Stock Markets Lead to Economic Growth?”, Journal of Policy Modeling, $32(4), 448-460$.

Demetriades, O.P. \& H.A. Khaled (1996), "Does Financial Development Cause Economic Growth? Time Series Evidence from 16 Countries", Journal of Development Economics, 51(2), 387-411.

Deidda, L. \& B. Fattouh (2008), “Banks, Financial Markets and Growth”, Journal of Financial Intermediation, 17(1), 6-36.

Dumetriscu, E.I. \& C. Hurlin (2012), "Testing for Granger Non-Causality in Heterogeneous Panels", Economic Modelling, 29(4), 1450-1460.

Durusu-Çiftçi, D. (2015), "Finansal Gelişme ve Ekonomik Büyüme İlişkisi: Bir Genişletilmiş Solow Büyüme Modeli Denemesi ve Ampirik Uygulama”, Yayınlanmamış Doktora Tezi, Pamukkale Üniversitesi Sosyal Bilimler Enstitüsü.

Erataş, F. \& A. Akçay (2012), Cari Açık ve Büyüme İlişkisinin Panel Nedensellik Analizi Ekseninde Değerlendirilmesi, <http://teacongress.org/papers2012/AKCAY-ERATAS.pdf>, 14.02.2019.

Erataş-Sönmez, F. \& Y. Sağlam (2017), "Financial Development and Economic Growth: A Comparative Analysis between Euro Area and Emerging-Developing Europe", Balıkesir University Journal of Social Sciences Institute, 20(38), 179-201.

Erataş-Sönmez, F. \& Y. Sağlam (2018), "Finansal Gelişme ve Ticari Açıklık ile Ekonomik Büyüme Arasındaki İlişki: Avrupa Dönüşüm Ekonomileri Örneği”, Anadolu Üniversitesi Sosyal Bilimler Enstitüsü Dergisi, 18(4), 59-72.

Goldsmith, R.W. (1969), Financial Structure and Development, London: Yale University Press.

Göçer, İ. (2013), “Ar-Ge Harcamalarının Yüksek Teknolojili Ürün İhracatı, Dış Ticaret Dengesi ve Ekonomik Büyüme Üzerindeki Etkileri”, Maliye Dergisi, 165, 215-240.

Greenwood, J. \& B. Jovanovic (1990), "Financial Development, Growth and the Distribution of Income", Journal of Political Economy, 98(5), 1076-1107.

Habibullah, M. \& Y. Eng (2006), "Does Financial Development Cause Economic Growth? A Panel Data Dynamic Analysis for the Asian Developing Countries", Journal of the Asia Pacific Economy, 11(4), 377-393.

Hadri, K. \& E. Kurozumi (2012), "A Simple Panel Stationarity Test in the Presence of Serial Correlation and a Common Factor", Economics Letter, 115(1), 31-34. 
Hassan M.K. \& B. Sanchez \& J.S. Yu (2011), "Financial Development and Economic Growth: New Evidence from Panel Data", The Quarterly Review of Economics and Finance, 51(1), 88104.

Hayaloğlu, P. (2015), "Kırılgan Beşli Ülkelerinde Finansal Gelişme ve Ekonomik Büyüme İlişkisi: Dinamik Panel Veri Analizi”, Ekonomik ve Sosyal Araştırmalar Dergisi, 11(11) 13111344.

Hurlin, C. \& E. Dumitrescu (2012), "Testing for Granger Non-Causality in Heterogeneous Panels", Economic Modelling, 29(4), 1450-1460.

International Monetary Fund - IMF (2012), Enhancing Financial Sector Surveillance in Low-Income Countries - Financial Deepening and Macro-Stability, Board Paper.

Joliffe, I.T. (2002), Principal Component Analysis (İkinci Bask1), New York: Springer-Verlag.

Letiao, N.C. (2010), "Financial Development and Economic Growth: A Panel Data Approach", Theoretical and Applied Economics, 17(2010)-10(551), 15-24.

Levine, R. (1991), “Stock Markets, Growth and the Tax Policy”, Journal of Finance, 46(4), 14451465.

Lucas, R.E. (1988), "On the Mechanics of Economic Development”, Journal of Monetary Economics, 22, 3-42.

Mankiw, G. \& D. Romer \& D.N. Weil (1992), "A Contribution to the Empirics of Economic Growth", Quarterly Journal of Economics, 2, 407-437.

McKinnon, R.I. (1973), Money and Capital in Economic Development, Washington, DC: The Brookings Institution.

Menyah, K. \& Ş. Nazlığlu \& W.R. Yemane (2014), "Financial Development, Trade Openness and Economic Growth in African Countries: New Insight from a Panel Causality Approach", Economic Modelling, 37, 386-394.

Mercan, M. \& İ. Göçer (2013), "The Effect of Financial Development on Economic Growth in BRICT Countries: Panel Data Analysis”, Journal of Economics and Social Sciences, 3(1), 199-216.

Mhadhbi, K. (2014), "Financial Development and Economic Growth: A Dynamic Panel Data Analysis", International Journal of Econometrics and Financial Management, 2(2), 4858.

Müslümov, A. \& G. Aras (2002), "Sermaye Piyasası Gelişmesi ve Ekonomik Büyüme Arasında Nedensellik İlişkileri: OECD Ülkeleri Örneği”, İktisat İşletme ve Finans, 17(198), 90100.

Öztürk, N. \& H. Kılıç-Darıcı \& F. Kesikoğlu (2011), "Ekonomik Büyüme ve Finansal Gelişme İlişkisi: Gelişmekte Olan Piyasalar için bir Panel Nedensellik Analizi”, Marmara Üniversitesi I.I.I.B.F. Dergisi, 15(1), 53-69.

Pagano, M. (1993), "Financial Markets and Growth: An Overview", European Economic Review, 37, 613-622.

Pradhan, R.P. \& D. Prateek \& S. Bele (2013), "Finance, Development and Economic Growth in BRICS: A Panel Data analysis", Journal of Quantitative Economic, 11(6), 308-322.

Pesaran, H.M. (2004), "General Diagnostic Tests for Cross Section Dependence in Panels", Working Paper 0435, University of Cambridge.

Pesaran, H.M. (2007), "A Simple Panel Unit Root Test in the Presence of Cross-Section Dependence", Journal of Applied Economics, 22, 265-312. 
Erataş-Sönmez, F. \& Y. Sağlam (2019), “The Relationship between Financial Development and Economic Growth for Developing Countries: Panel Causality Analysis”, Sosyoekonomi, Vol. 27(42), 87-106.

Pesaran, H.M. \& T. Yamagata (2008), “Testing Slope Homogeneity in Large Panels”, Journal of Econometrics, 142, 50-93.

Rachdi, H. \& H.B. Mbarek (2011), "The Causality between Financial Development and Economic Growth: Panel Data Cointegration and GMM System Approaches", International Journal of Economics and Finance, 3(1), 143-151.

Robinson, J. (1954), The Rate of Interest and Other Essays, London: Macmillan.

Romer, P.M. (1986), "Increasing Returns and Long-run Growth", Journal of Political Economy, 94(5), 1002-1037.

Romer, P.M. (1990), “Endogenous Technological Change”, The Journal of Political Economy, 98(5), 71-102.

Sağlam, Y. \& F. Erataş-Sönmez (2017), "Finansal Gelişme ve Ekonomik Büyüme Arasındaki İlişki: Avrupa Geçiş Ekonomileri Örneği”, Eskişehir Osmangazi Üniversitesi IIIBF Dergisi, 12(1), 121-140.

Sağlam, Y. \& H.A. Egeli (2013), "İmalat Sanayinin Gelişimi ve Dışa Açılık Üzerine Bir Uygulama: 1996-2011 Türkiye Örneği”, Finans, Politik ve Ekonomik Yorumlar Dergisi, 50(583), 27 42.

Sağlam, Y. \& H.A. Egeli \& P. Egeli (2017), "Gelişmiş ve Gelişmekte Olan Ülkelerde Ar\&Ge Harcamaları ve Ekonomik Büyüme Arasındaki İlişki: Panel Veri Analizi”, Sosyoekonomi, 25(31), 149-165.

Saint-Paul, G. (1992), “Technological Choice, Financial Markets and Economic Development”, European Economic Review, 36(4), 763-781.

Schumpeter, J.A. (1911), Theorie der Wirtschatlichen Entwicklung, Leipzig: Duncker\&Humblot.

Schumpeter, J.A. (1934), The Theory of Economic Development: An Inquiry into Profits, Capital, Credit, Interest, and the Business Cycle, Çev. R. Opie, Cambridge: Harvard University Press.

Shaw, S.E. (1973), Financial Deepening in Economic Development, Oxford University Press.

Sul, D. \& P.C.B. Phillips \& C.Y. Choi (2005), "Prewhitening bias in HAC Estimation", Oxford Bulletin of Economics and Statistics, 67(4), 517-546.

Svirydzenka, K. (2016), "Introducing a New Broad-based Index of Financial Development", IMF Working Paper, 1-43.

Şahin, D. (2017), "Farklı Gelir Gruplarındaki Ülkelerde Finansal Gelişme ve Ekonomik Büyüme İlişkisinin Analizi”, International Journal of Economics and Management, 4(4), 61-74.

Toda, H.Y. \& T. Yamamoto (1995), "Statistical Inference in Vector Autoregressions with Possibly Integrated Processes", Journal of Econometrics, 66(1-2), 225-250.

Westerlund, J. (2008), "Panel Cointegration Tests of the Fisher Effect", Journal of Applied Econometrics, 23(2), 193-233.

Wu, J.L. \& H. Hou \& S.Y. Cheng (2010), "The Dynamic Impacts of Financial Institutions on Economic Growth: Evidence from the European Union", Journal of Macroeconomic, 32(3), 879-891. 